\title{
A SWOT Analysis Of Competitive Knowledge From Social Media For A Small Start-Up Business
}

Gail Brooks, University of Mary Washington, USA

Alan Heffner, University of Mary Washington, USA

Dave Henderson, University of Mary Washington, USA

\begin{abstract}
The analysis of data from social media sites can provide useful decision-making information for businesses; however, can small businesses with limited budgets and limited technical expertise compete in this new social media driven market? This study provides a proof of concept for increasing a company's competitive knowledge through the use of the Strengths, Weaknesses, Opportunities, and Threats (SWOT) framework model by gathering qualitative data about the use of social media from employee interviews. By increasing the competitive knowledge through evaluating the results of the SWOT analysis, this small start-up company will have a strategic plan for increasing their competitive advantage. The authors present the results of the study in the form of practical recommendations for short-term and long-term implementation. Several of the shortterm and long-term recommendations are substantiated through prior research studies. Future research could include a follow-up study of this company using a SWOT framework tool or other methodologies to indicate what social media tools and strategies provide the most beneficial competitive knowledge for a small business, and why. Additionally, comparing the results from this study with a similar study of a different small start-up business could lead to the design of a model for other small businesses trying to increase their competitive knowledge through the effective use of social media.
\end{abstract}

Keywords: SWOT; Social Media; Small Start-Up Business; Competitive Knowledge; Case Study

\section{INTRODUCTION}

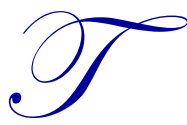

he purpose of this study is to use the well-known SWOT framework model to evaluate a small startup business's use of social media from a competitive knowledge perspective. While the SWOT framework can provide valuable insight into a company's competitive position, previous research has largely used other methods or discussed the impact of social media on a firm's competitiveness (Mangold \& Faulds, 2009; Kaplan \& Haenlein, 2010; Kietzman, Hermkens, McDarthy, \& Silvestre, 2011; Xiang \& Gretzel, 2010; Hanna, Rohm, \& Crittenden, 2011).

Conversely, considerable research utilizing the SWOT framework model to analyze the use of social media is not from the direct perspective of strategic competitive knowledge. Sample themes in this body of research include: collaboration and training in educational environments (Thinesse-Demel, 2010; Grosseck \& Holotescu, 2011; Bosman \& Zagenczyk, 2011), interaction and collaboration in library environments (Fernandez, 2009; Bodnar \& Doshi, 2011; Lin \& Ranjit, 2012), managing the use of social media in different business environments (Montalvo, 2011), using social media in product development (Bertoni, Chirumalla, \& Johansson, 2012), and social media for collaboration in government (Wooley, 2010). Huckfield (2012) used SWOT to evaluate the use of social media as one way to promote business by having employees participate in social media conversations. Even though this is somewhat similar to the research performed in this study, the type of business is very different and Huckfield's (2012) study used other methodologies in addition to SWOT. 
As such, this study separates itself from previous research by illustrating how the SWOT framework can be used to help a company examine the impact of social media on its competitive position. More specifically, this study pairs SWOT, a framework model used for over half a century, with a fairly new Web 2.0 technology, social media. A SWOT analysis is recommended in the research by both Zack (1999) for creating knowledge strategy and by Rothaermel (2013) for increasing a company's competitive advantage. Current research indicates the business uses of Web 2.0 social media technologies and the knowledge created from them have become so important to business operations that many companies already include them in their marketing, risk management, and customer relationship strategies (Brandel, 2010). The information derived from social media analysis becomes competitive knowledge when the organization uses it to understand the opportunities and limitations associated with reaching its desired competitive position in the marketplace (Zack, 1999). As such, SWOT is an example of a framework that can be used to understand these opportunities and limitations.

This study will provide a proof of concept for the use of the SWOT framework tool in a different way from most previous research; to evaluate the use of social media in a small start-up business for the purpose of increasing their competitive knowledge and, as a result, to increase their competitive advantage. The following research questions will provide a focus and a practical framework for the study.

- $\quad$ How can SWOT provide a snapshot of a company's use of social media?

- How can a small startup business utilize the data and information on social networks from a SWOT analysis to become more competitive?

- How can key guidelines for the use of social media suggested in the literature apply to the company's use of social media?

Answers to these questions and results of the data analysis substantiate the ability to utilize the SWOT framework model for analyzing business impacts of technological advances and providing the foundation for shortterm and long-term recommendations supporting a strategic management plan to enhance the company's competitive advantage without expending substantial resources. This research method can be used for future research of other small start-up companies or other types of businesses.

\section{METHODOLOGY}

The subject company of this research is a small, family-owned and operated inn catering to special events; e.g., weddings, holiday parties, and corporate meetings. It is a relatively new startup. At the time of this study, the company was using four social media applications: Facebook, Twitter, LinkedIn, and a company blog. The company website contained links to all four applications.

The authors conducted extensive interviews with six individuals - the owners and several key employees of the company - utilizing a structured interview questionnaire consisting of 26 questions. Due to the exploratory nature of this study, the researchers chose an open-ended questionnaire format to obtain in-depth insight into the company's use of social media. When relevant, they used follow-up questions to probe for additional information.

Each interview lasted between 45 and 90 minutes. Two authors were present during the interviews. They each transcribed their extensive interview notes, and later merged them into one document for analysis. Key ideas about the strengths, weaknesses, opportunities, and threats, as they relate to the use of social media, were extracted from the recorded data to build the SWOT table.

In turn, the SWOT information was used to design short-term and long-term recommendations, many of which were supported by previous research. The list provides a practical application for this research in that it can be used by the company to expand the use of social media to strategically align it with the company's mission and goals. 


\section{BACKGROUND}

\section{SWOT as a Research Framework}

The SWOT analysis is a well-known, popular, and advantageous tool for providing qualitative information in an organized fashion. Weihrich is often recognized as the first person to identify the advantages of using this tool (Friesner, 2011). Weihrich's (1982) research discusses the framework as a way for companies to list threats, opportunities, weaknesses, and strengths (TOWS) for identifying relationships and creating strategies. The SWOT framework model has been presented by many as a clear and straight forward way to depict information about a company from an internal perspective through strengths and weaknesses and from an external perspective through opportunities and threats (Hill \& Westbrook, 1997; Coman \& Ronen, 2009). The flexibility of SWOT allows companies to display different combinations of the strengths, weaknesses, opportunities, and threats (Ghazinoory, Abdi, \& Azadegan-Mehr, 2011). These different combinations provide multiple viewpoints and offer a starting point for strategic planning (Helms \& Nixon, 2010). Additionally, the information from SWOT can identify factors that are an important part of a decision making process (Yüksel \& Dagdeviren, 2007). SWOT is one of the most used tools assisting a company in defining actionable strategies (Coman \& Ronen, 2009). It is not intended to be used as an end in itself, but as part of an ongoing process for strategy development (Dyson, 2004).

The flexibility of SWOT allows its use with newer ideas (Dyson, 2004). For example, researchers recognize SWOT as one of the techniques that could be used to help companies move toward the development of a knowledge strategy (Zack, 1999) and competitive knowledge (Gray, 2010). Work by Rothaermel (2013) supports these strategies by arguing that the insights synthesized from a SWOT analysis increase the chances of gaining a competitive advantage in a business' marketplace.

In 2011, Ghazinoory et al. conducted a thorough literature review of the SWOT framework that included over 500 papers up through 2009. Their review of the research indicates that SWOT began as a strategic planning tool, but, over the years, has been utilized in many different areas. They divided the SWOT literature into three categories: methodological, case study, and applied-methodological. This study fits into their case study category as it uses SWOT to "guide the practice, and offer recommendations for action" (Ghazinoory et al., 2011, p. 30). All of these facts make SWOT a valuable tool for small start-up companies. This is supported by Reed (2013) who determined that SWOT can be an excellent tool to help determine a growth path for companies; it is a tool that can be used with existing company resources and it can provide valuable information for decision making. Small startup companies would most likely fall into this category.

\section{Why Social Media is Important in Today's Business Environment}

According to Boyd and Ellison's (2007) discussion of the history of social network sites (SNS), the idea of social media began approximately fifteen years ago. In the late 1990's SNSs were very limited, allowing users to only create personal profiles and connect to "friends" (Boyd \& Ellison, 2007). Technologies available for SNSs at that time were part of the web known as Web 1.0 and consisted mainly of static web pages and file management (O'Reilly, 2005). Around 2001, professionally affiliated SNSs started to appear, allowing users to connect and collaborate for business and professional purposes (Boyd \& Ellison, 2007). Soon after, Web 2.0 technologies created an online environment of electronic media sharing and user generated content, giving users the ability to create, aggregate, link, and share created content instantly (O'Reilly, 2005).

These continuously created social media conversations take place among several different types of consumers: a current customer, a prospective customer, a fan of the product or service, or a critic of the product or service (Ramsay, 2010). Product branding and customer relationships are two business areas that can be affected positively or negatively by the way organizations choose to participate in the conversations (Ramsay, 2010). Not only should organizations participate in these conversations, they should initiate activities that help to answer the question why consumers do or do not buy their products and services (Zack, 1999). Knowledge produced from these conversations can help to positively impact product branding and customer relationships. To complicate matters, these conversations are not just about product reviews and services received during the purchase; they are taking place during all the steps in the buying process. These steps are described by Court, Elzinga, Mulder, and Vetvik 
(2009) as the "consumer decision journey," and include the following phases: consideration of certain products/services, evaluation of those products/services, selection and purchase of the products/services, and experiencing the products/services.

It is clear that social media communications are increasingly influencing customer perceptions and purchase decisions (Court et al., 2009; Edelman, 2010). The reach of these communications is spreading in a "viral" fashion. A study conducted by Fulgoni (2011) of three successful companies' Facebook communications estimated the increased reach to be between $125 \%$ and $169 \%$ when friends of fans were included in the companies' communications.

Social networks continue to gain popularity and are fast becoming the preferred communication channel for personal and business interactions (Ramsay, 2010). Van de Ketterij's (2012) report on the current usage of social networking showed that people worldwide spend one out of every five minutes online in some type of social networking environment. If companies do not begin to listen to these social media conversations and use them to create competitive knowledge, they will continue to lose any competitive advantage they may have (Ramsay, 2010). As such, using social media to better understand why customers buy (or do not buy) an organization's products or services undoubtedly plays an important role in establishing a competitive position. User generated content from social media sites has changed the way people find and buy products and services, a trend identified by Steve Hasker, Nielsen's President of Media Products and Advertiser Solutions (Innovating to Keep up with the Everchanging Consumer, 2011). This trend has an enormous potential impact on businesses, as more and more customers find products from social media conversations. Often they continue to discuss the product/service in social media environments after the completed purchase (Court et al., 2009).

It is just as important for employees of a firm to know when and how to respond to communications within social media environments (Ramsay, 2010; Brandel, 2010). Ramsay (2010) gives examples of how a lack of response or a negative response to complaints can damage a business' reputation. At the same time, negative effects can ensue when businesses participate in unsolicited social media conversations. They may be interpreted as "pushy" or unwanted, similar to spam email and, many times, will be ignored. This is not an effective way to increase customer loyalty (Ramsay, 2010).

Finally, social media allows information to be spread rapidly from one person to many people through selfreplication (Phillips, McFadden, \& Sullins, 2010). Social networks have the built-in capability for this replication, and businesses realize a larger reach can be achieved through using social networks in this manner (Phillips et al., 2010). This "viral marketing" concept has been beneficial to companies trying to reach different prospective consumer groups. Fulgoni's (2011) study of three companies' use of social media communications illustrates this concept and shows that when a company sends communications through a social media channel such as Facebook, "Friends of Fans" are much more likely to visit the company's website than someone just "surfing" the Internet.

\section{ANALYSIS OF DATA}

The authors used their notes from the interviews for data analysis. First, they independently evaluated the questionnaire data, and then used a traditional SWOT analysis (see Table 1) to provide a visible representation of their company's strengths, weaknesses, opportunities, and threats as they specifically relate to social media. 
Table 1: SWOT Analysis of Social Media Use

\begin{tabular}{|c|c|}
\hline Strengths & Weaknesses \\
\hline $\begin{array}{l}\text { 1. Excellent comments and reviews in social media } \\
\text { communications from the general public, customers, and } \\
\text { vendors attesting to the company's facility, events, and } \\
\text { customer service. } \\
\text { 2. Use of social media to customize and personalize } \\
\text { customers' experiences. } \\
\text { 3. A young staff familiar with using social media, } \\
\text { facilitating a more natural communication with targeted } \\
\text { groups of prospective customers. }\end{array}$ & $\begin{array}{l}\text { 1. Limited resources and time. } \\
\text { 2. Not currently reaching all desired customer groups. } \\
\text { 3. No ROI information from the use of social media. } \\
\text { 4. Limited exposure in the social media environment. } \\
\text { 5. No set schedule for updating information through social } \\
\text { media. }\end{array}$ \\
\hline $\begin{array}{l}\text { 1. Upportunities } \\
\text { prospective customer groups within the social media } \\
\text { environments to showcase unique characteristics of the } \\
\text { business (Porter, 1980). } \\
\text { 2. Develop strategies for using social media to increase } \\
\text { company exposure. } \\
\text { 3. Develop policies for using social media to align with } \\
\text { company's goals. } \\
\text { 4. Integrate and expand current technologies to obtain } \\
\text { better decision-making information and optimize } \\
\text { business processes. } \\
\text { 5. Coordinate the use of marketing materials with social } \\
\text { media to increase exposure through cross-platforms and } \\
\text { cross- promotion. } \\
\text { 6se emerging new tools for social media content } \\
\text { analysis. }\end{array}$ & $\begin{array}{l}\text { Threats } \\
\text { 1. Changing social media technologies. } \\
\text { 2. Customer communication media preferences may } \\
\text { frequently change. } \\
\text { 3. Regional competitors increased utilization of social } \\
\text { media technologies. }\end{array}$ \\
\hline
\end{tabular}

Results from an analysis of interview data and the SWOT analysis suggest the company has been successful using social media for distinct areas of the business, such as communicating with current and past customers, and posting information about upcoming events. Limited resources and time are the main contributors to the list of weaknesses. These are not surprising for a small startup company that has not been in business very long. The threats are related to constantly changing and new social media technologies, and the ways these social media technologies are altering business processes such as marketing and customer relationship (Top 10 Strategic Technology Trends for 2012, 2012). The opportunities to expand and integrate the use of social media provide the company with several options that are discussed in the Findings section.

The second triangulation analysis included examination of quantitative data obtained from the analysis reports provided by the company for two non-consecutive months. Because of the short period of time the company has been in business, a limited amount of data was available for analysis. Therefore, it is difficult to measure the effectiveness or ROI of the social media tools utilized by the company. The following list describes the information included in the monthly reports that were used for the quantitative data analysis.

- $\quad$ The number of visits to the company website for each day of the month.

- $\quad$ The total number and percentage of visits by country and city.

- $\quad$ The duration of each visit.

- $\quad$ Outgoing links.

- $\quad$ Referrer types (e.g., social network).

The authors drew the following conclusions related to social media from the website traffic data report:

- $\quad$ the percentage of total visitors from social networking sites to the company website is $2.1 \%$. The majority of the visits link from search engine websites, and

- $\quad 80 \%$ of the visitors to the company website go directly to the company's blog site, the outgoing link. 
Figure 1 demonstrates that visits to the company website tend to increase during the middle of the week and decrease during the weekend days. This seems logical given that many events occur on weekends and would be scheduled during a weekday.

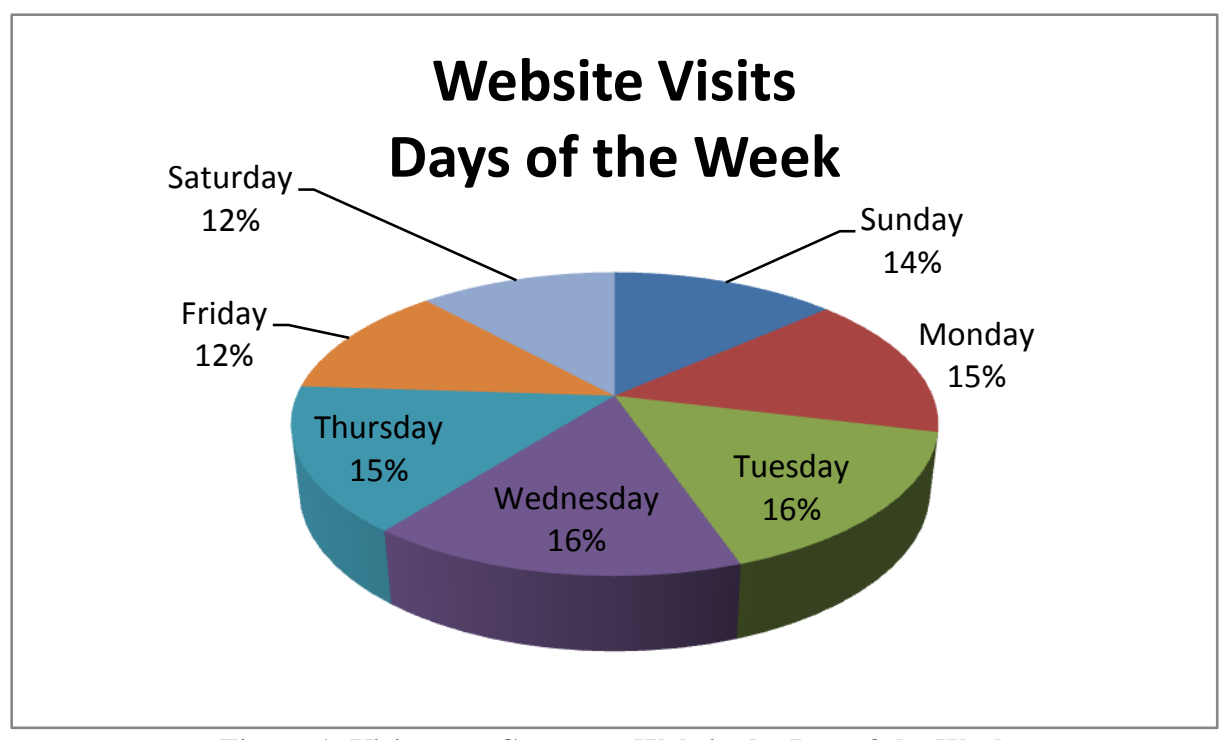

Figure 1: Visitors to Company Website by Day of the Week

Figure 2 illustrates the majority of visitors to the website are locally and regionally located when visiting the website. Local is defined to be within thirty miles of the company. Regional is defined to be within sixty miles of the company. Within state includes all data for the state minus local and regional data.

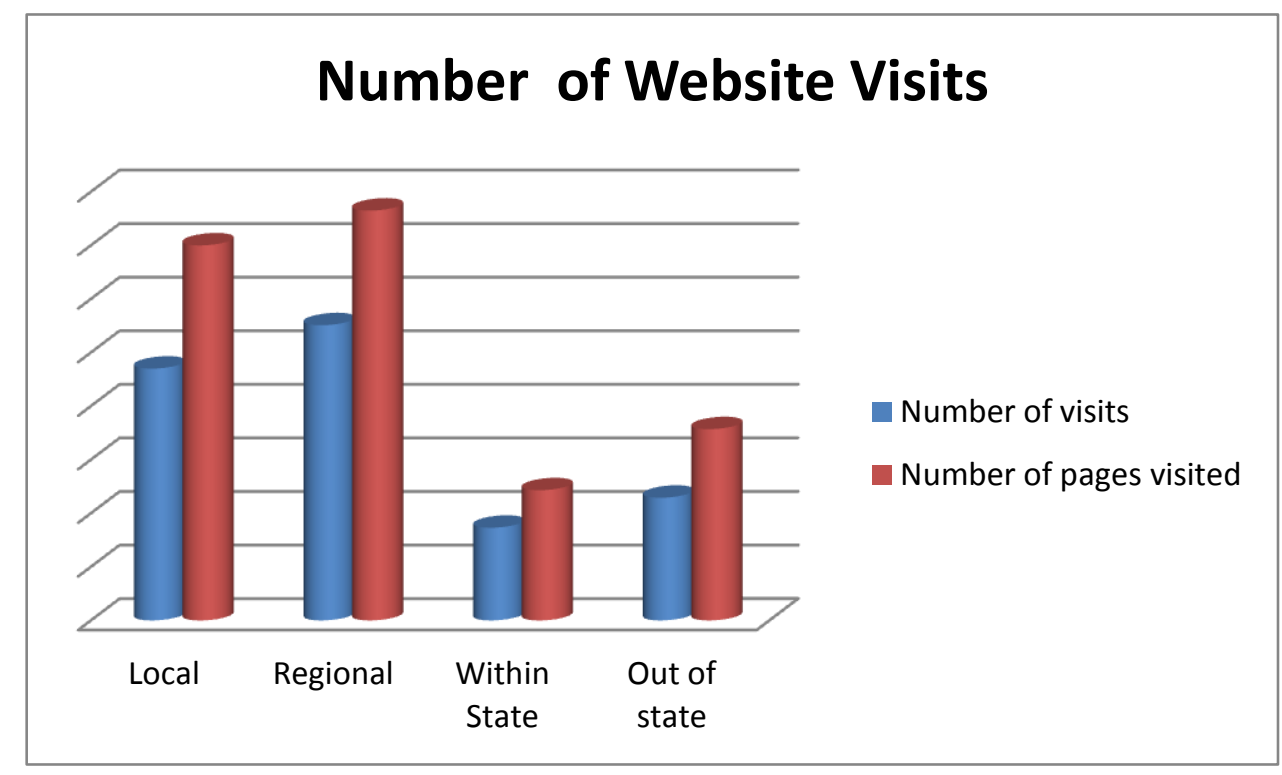

Figure 2: Relationship of Website Visits by Location

\section{FINDINGS AND RECOMMENDATIONS}

The findings suggest a number of short-term and long-term recommendations that address the research questions initially proposed by the authors, specifically, how the company owner-operators can widen their customer base, increase their market share, increase their revenue, and better use social media to improve their 
competitive position in the marketplace. The authors believe that many of the recommendations are applicable to other small businesses seeking to use social media to gain a competitive knowledge advantage.

The results of the study are summarized below under each related research question.

1. How can SWOT provide a snapshot of a company's use of social media?

Data was collected from interviews that involved questions related to how the company uses social media. The data from the interviews was analyzed by the authors independently. Trends and patterns were correlated from the independent analysis which allowed the authors to easily categorize the company's use of social into strengths and weaknesses comprising the internal appraisal of the company's use of social media (Dyson, 2004). Further research of the social media and technological environment for this type of business gave the researchers insight for developing opportunities and threats (Dyson, 2004). It was a straight forward method that has been used successfully for decades and continues to be used in many business areas as described in the literature review by Ghazinoory et al. (2011). SWOT proved to be an effective way to analyze the company's use of social media.

2. How can a small startup business utilize the data and information on social networks to become more competitive?

Using relatively inexpensive and free social media tools can help a company get started with social media. This company is currently using four of the most well-known social media applications, Facebook, Twitter, LinkedIn, and a company blog. A free analysis tool is currently being used to monitor the traffic on the company website, which provides information about the traffic visiting the web pages on the company website. This information can be helpful, but it does not provide any type of content analysis associated with conversations taking place through social media. The company has already begun to address this issue by converting a part-time employee to full time with the majority of the employee's work to focus on keeping the company website updated and increasing the company's presence on the different social media sites. This staff member should review the open source analysis tools available for analyzing the content from the four social media applications. Even small companies should have a part-time or a portion of a full-time employee's time dedicated to this area in order to be able to increase their competitive advantage.

3. How can key guidelines for the use of social media suggested in the literature apply to the company's use of social media?

Using the SWOT analysis table as a guide, the authors developed a list of short-term and long-term recommendations to answer research question number three and connected them to previous research where applicable.

\section{Short-Term Recommendations}

- Maintaining effective communication and collaboration on four social networking sites is a challenge, particularly for a small, start-up business with limited resources. To best leverage current resources, decide which ones are most effective or best align with the company's strategic goals.

- $\quad$ Develop a strategy for using the selected social media tools (Hughes, 2011; Sheth, 2012; Fulgoni, 2011; Ramsay, 2010). Some examples for strategies in this literature include:

- plan how many tweets to send per time period such as week or day,

$\circ$ establish yourself as an expert in your area by selecting questions to answer about your business,

$\circ$ only tweet promotional material about $10 \%$ of the time,

- create a "sense of urgency" if there is limited availability for the services during a particular period of time, and

- use social media venues to ask questions that might be of interest to current, past, and prospective customers to encourage active participation and communication. 
- $\quad$ Expand the use of social media to incorporate other services offered by the business.

- The company has established an excellent reputation in a short period of time. Continue doing what has proved to work. For example, sharing photos of the company's facilities and recent events on the different social media sites and letting people comment on them, and using the company blog to host a monthly newsletter and distributing it by email.

- Review and update content on a predetermined schedule to ensure information is accurate and current.

- $\quad$ Consider the interrelationships among the different social media sites and ensure that synergy is attained among them. For example, how does the content on the company blog relate to tweets and the information being posted on Facebook? Should the content be the same or should there be different consumer populations addressed by each one?

\section{Long-Term Recommendations}

- $\quad$ Continue to use analytics for the company web page and social media sites. Monitor the changes for each one; for example, usage rates, posts per week, percent of traffic to website, number of fans, fan interactions per post, etc. (Phillips et al., 2010).

- Analyze the effectiveness of the social media tools at least quarterly by using current social media analytical tools or using qualitative and quantitative analyses. Possible quantitative measurements include the growth of followers as compared to the increase in the number of customers and events and the increase in communication compared to the increase in the social interaction. For example, has the increased social media interaction using strategically focused information caused an increase in the number of people reading, following, and commenting on the different social media networks? Have any of these people become customers or recommended the company's services to others that became customers?

- $\quad$ Create a strategy for "social marketing" that aligns with the company's mission and goals and that will continue to build a strong allegiance with customers (Phillips et al., 2010).

- Create an official policy for social media communications. Topics might include social media etiquette, marketing information, and standards for terminology, consistent representation of the company, topics not to discuss, and information that should be included whenever possible. Such a policy will become more important as the company grows and adds more personnel.

\section{CONCLUSIONS}

The purpose of this study was to utilize the SWOT framework to determine the use of social media for a small start-up company. SWOT proved to be an adaptable framework tool for analyzing the use of social media to provide information for increasing a company's competitive knowledge. Increasing an organization's competitive knowledge through the use of social media has many benefits. The current literature on social media clearly demonstrates these competitive benefits for all types of organizations (Zack, 1999; Hughes, 2011; Sheth, 2012; Fulgoni, 2011; Ramsay, 2010; Bughin, Byers, \& Chu, 2011).

The company selected for this study was a small family owned business operating for a few years at the time of this research. The business mainly used four social media applications including Facebook, Twitter, LinkedIn, and a company blog. The researchers collected qualitative data by interviewing several employees, including the owners, using an open ended question format to encourage an open dialogue about the company's use of social media.

The researchers independently analyzed the answers and identified trends and common themes given throughout the answers. This information was used to generate a SWOT analysis in order for the company to gain a better understanding of the strengths, weaknesses, opportunities, and threats based on the current use of the social media applications. Research by Zack (1999) covering over 25 organizations reveals that an organization's management of its knowledge must align with the context of the organization's overall business strategy. One of the most well-known ways to organize this alignment is the SWOT analysis.

Strengths of this company include the good reputation of the company and the positive feedback from customers. Even though the number of employees is small, the majority of the employees are young, energetic, and 
familiar with how to use social media. According to a survey conducted by Bughin et al. (2011) with more than four thousand respondents from a variety of different organizations, the benefits of using social media to communicate with customers include increased marketing effectiveness, increased customer satisfaction, and a reduction of marketing costs.

The main weakness is that at the time of this study, the company had not had the opportunity to hire an employee that could be dedicated to monitoring and pursuing business opportunities through social media. The biggest threat is the competitive use of social media by similar organizations. The survey results from a study by Bughin et al. (2011) show that blogs and social media information provide valuable knowledge related to competitors and marketing.

The authors provided short-term and long-term recommendations, many supported through previous research. In the short-term, it was recommended that the company look seriously at how to best utilize the social media and prepare a plan to follow to efficiently and effectively maintain communications and collaboration with current and prospective customers. Long term plans should include ways of measuring the ROI on the use of social media, creating a strategy for marketing through social media that aligns with the business' goals and mission, and designing a policy for maintaining positive and streamlined communication with the intended audience through social media.

Approximately two months of data collected from the company's website and provided by the company allowed the authors to perform limited quantitative analysis. A triangulation of the qualitative data from the interviews and the quantitative data from the company website analysis report gives additional insights into the use of social media by the company, and reinforces the recommendations presented to the company. For example, the quantitative data indicates that $80 \%$ of the visitors to the company website go directly to the company's blog site, the outgoing link. The fact that the majority of the visitors are linking to the company's blog site can be used to leverage this particular social media venue using several of the short-term recommendations listed under "Develop a strategy for using the selected social media tools."

The results of this study are relevant from both a practical and theoretical perspective. They provide practical recommendations for increasing a small start-up business' competitive knowledge through the use of social media. The theoretical implication of the study is the contribution of a proof of concept for using the well-known SWOT framework tool to examine the use of social media and using the results of this examination to provide recommendations to increase the competitive knowledge for a small start-up business.

\section{LIMITATIONS AND RECOMMENDATIONS FOR FUTURE RESEARCH}

This study is based on a single start-up company with a small number of employees. The amount of data available for analysis was limited due to the short period of time the company has been operating and using social media. Limited available data covering a short period of time proved to be one of the biggest challenges of this study.

The authors believe that a future study of what recommendations were implemented by the company in this study, and the results of that implementation, would be of value. A follow-up study using a SWOT framework tool could indicate what social media tools and strategies provide the most beneficial competitive knowledge for a small business, and why. Such data would be useful for other small businesses seeking to align their business strategy with the knowledge provided by an analysis of their use of social media.

It is also recommended that a comparison study be done comparing the subject company with a small manufacturing company and a nonprofit organization. Knowledge gleaned from such a comparison study could lead to the development of a model applicable to other small businesses seeking to improve their competitive knowledge using social media. 


\section{AUTHOR INFORMATION}

Gail Brooks is a Professor of Computer Information Systems in the College of Business at the University of Mary Washington. She teaches courses in management information systems, knowledge management systems, database management systems, and IT Project Management. Her research focuses on the use of information systems for competitive knowledge and assessment. E-mail: gbrooks@umw.edu (Corresponding author)

Alan Heffner is a retired Professor of Management in the College of Business at the University of Mary Washington. He taught courses in organization theory and design, organizational behaviour, management, and strategic management. His research focuses on organization design, collaboration in science, and innovation in organizations. E-mail: agheffner2@gmail.com

Dave Henderson is an as Assistant Professor of Accounting in the College of Business at the University of Mary Washington. He teaches Principles of Accounting, Managerial Accounting, and Accounting Information Systems. He has accumulated over eight years of industry experience in various roles including financial analyst, financial systems developer, and project manager. His research focuses on adoption, control, and development of accounting information systems. He has published numerous articles on these topics. E-mail: dhender3@umw.edu

\section{REFERENCES}

1. Bertoni, M., Chirumalla, K., \& Johansson, C. (2012). Social technologies for cross-functional product development: SWOT analysis and implications. System Science (HICSS), 2012 45th Hawaii International Conference, pp. 3918, 3927, 4-7 Jan. 2012. doi: 10.1109/HICSS.2012.538

2. Bodnar, J., \& Doshi, A. (2011). Asking the right questions: A critique of Facebook, Social Media, and Libraries. Public Services Quarterly, 7(3-4), 102-110. doi:10.1080/15228959.2011.623594

3. Bosman, L., \& Zagenczyk, T. (2011). Revitalize your teaching: creative approaches to applying social media in the classroom. In B. White, I. King, \& P. Tsang (Eds.), Social media tools and platforms in learning environments (pp. 3-15). Berlin Heidelberg: Springer.

4. Boyd, D. M., \& Ellison, N. B. (2007, October). Social network sites: Definition, history, and scholarship. Journal of Computer -Mediated Communication, 13(1), 210-230.

5. $\quad$ Brandel, M. (2010, July 12). Are you listening? ComputerWorld, 13-14.

6. Bughin, J., Byers, A. H., \& Chu, M. (2011, November). How social technologies are extending the organization. McKinsey Quarterly, 1-10.

7. Coman, A., \& Ronen, B. (2009). Focused SWOT: Diagnosing critical strengths and weaknesses. International Journal of Production Research, 47(20), 5677-5689.

8. Court, D., Elzinga, D., Mulder, S., \& Vetvik, O. (2009). The consumer decision journey. McKinsey Quarterly, 3, 96-107.

9. Dyson, R. G. (2004). Strategic development and SWOT analysis at the University of Warwick. European Journal of Operational Research, 152(3), 631-640.

10. Edelman, C. D. (2010, December). Branding in the digital age your're spending your money in all the wrong places. Harvard Business Review, 62-69.

11. Fernandez, J. (2009). A SWOT analysis for social media in libraries. Retrieved September 12, 2011 from http://works.bepress.com/joe_fernandez/4

12. Friesner, T. (2011). History of SWOT analysis. Marketing Teacher, 2000-2010. Retrieved September 27, 2013 from http://www.marketingteacher.com/swot/history-of-swot.html

13. Fulgoni, G. (2011, September 9). "You've got to see it!": What social media marketers can learn from broadway success. Retrieved September 12, 2011 from http://blog.comscore.com/2011/09/ what_social_marketers_can_learn_from_broadway.html

14. Ghazinoory, S., Abdi, M., \& Azadegan-Mehr, M. (2011). SWOT methodology: A state-of-the-art review for past, a framework for future. Journal of Business Economics and Management, 12(1), 24-48.

15. Gray, P. (2010). Competitive intelligence. Business Intelligence Journal, 15(4), 31-37.

16. Grosseck, G., \& Holotescu, C. (2011). Teacher education in 140 characters- microblogging implications for continuous education, training, learning and personal development. Procedia Social and Behavioral Sciences, 11, 160-164. 
17. Hanna, R., Rohm, A., \& Crittenden, V. L. (2011). We're all connected: The power of the social media ecosystem. Business Horizons, 54, 265-273.

18. Helms, M. M., \& Nixon, J. (2010). Exploring SWOT analysis-where are we now?: A review of academic research from the last decade. Journal of Strategy and Management, 3(3), 215-251.

19. Hill, T., \& Westbrook, R. (1997). SWOT analysis: It's time for a product recall. Long Range Planning, 30(1), 46-52. Retrieved September 17, 2013 from http://www.sciencedirect.com/science/ article/pii/S0024630196000957

20. Huckfield, S. (2012). The role of nurses in promoting a business. Veterinary Nursing Journal, 27, $267-268$. doi: 10.1111/j.2045-0648.2012.00194.x

21. Hughes, P. (2011). 6 ways to be a better small business on twitter. Retrieved February 21, 2012 from http://blog.swipelyworks.com/twitter-marketing/6-ways-to-be-a-better-small-business-on-twitter

22. Innovating to Keep up with the Ever-changing Consumer. (2011, June 22). Retrieved September 72011 from http://blog.nielsen.com/nielsenwire/media_entertainment/innovating-to-keep-up-with-the-everchanging-consumer/

23. Kaplan, A. M., \& Haenlein, M. (2010). Users of the world, unite! The challenges and opportunities of social media. Business Horizons, 53, 59-68.

24. Kietzman J. H., Hermkens, K., McDarthy, I. P., \& Silvestre, B. S. (2011). Social media? Get serious! Understanding the functional building blocks of social media. Business Horizons, 54, 241-251.

25. Lin, Y., \& Ranjit, K. (2012). Using social media to create virtual interest groups in hospital libraries. The Grey Journal, 8(1), 35-42.

26. Mangold, W. G., \& Faulds, D. J. (2009). Social media: The new hybrid element of the promotion mix. Business Horizons, 52, 357-364.

27. Montalvo, R. E. (2011). Social media management. International Journal of Management \& Information Systems, 15(3), 91-96.

28. O'Reilly, T. (2005, September 30). What is Web 2.0 design patterns and business models for the next generation of software. Retrieved March 21, 2012 from http://oreilly.com/web2/archive/what-is-web20.html

29. Phillips, M., McFadden, D. T., \& Sullins, M. (2010, March). How effective is social networking for direct marketers? Journal of Food Distribution Research, 96-100.

30. Porter, M. E. (1980). Competitive strategy: Techniques for analyzing industries and competitors. New York: The Free Press.

31. Ramsay, M. (2010, October 11). Social media etiquette: A guide and checklist to the benefits and perils of social networking. Database marketing \& Customer Strategy Management, 17(3/4), 257-261.

32. Reed, D. (2013) SWOT your way to the future. Industrial Management, 55(2), 23-26.

33. Rothaermel, F. T. (2013). Strategic management. New York: McGraw-Hill/Irwin.

34. Sheth, R. (2012, January 31). Spending too much time on twitter. Retrieved from http://smallbiztrends.com/ 2012/01/spending-too-much-time-on-twitter.html

35. Thinesse-Demel, J., (2010). Learning regions in Germany. European Journal of Education, 45(3), 437-450.

36. Top 10 Strategic Technology Trends for 2012. (2012). Retrieved February 29, 2012 from http://www.gartner.com/technology/research/top-10-technology-trends/

37. van de Ketterij, B. (2012, January 4). It's a social world top 10 need-to-knows about social networking and where it's headed. Retrieved March 1, 2012 from http://www.comscore.com/Press_Events/ Presentations_Whitepapers/2011/it_is_a_social_world_top_10_need-to-knows_about_social_networking

38. Weihrich, H. (1982). The TOWS matrix - a tool for situational analysis. Long Range Planning, 15(2), 5466.

39. Wooley, K. (2010). Collaboration: The new default setting. IEEE Engineering Management Review, 38(3), 92.

40. Xiang, Z., \& Gretzel, U. (2010). Role of social media in online travel information search. Tourism Management, 31, 179-188.

41. Yüksel, İ., \& Dagdeviren, M. (2007). Using the analytic network process (ANP) in a SWOT analysis-A case study for a textile firm. Information Sciences, 177(16), 3364-3382.

42. Zack, M. (1999). Developing a knowledge strategy. California Management Review, 125-145. 
NOTES 